\title{
Association of LEC and tnpA Helicobacter pylori genes with gastric cancer in a Brazilian population
}

\author{
Rejane Mattar*, Maria S Monteiro, Sergio B Marques, Bruno Zilberstein, Cláudio L Hashimoto, Flair J Carrilho
}

\begin{abstract}
Background: $H$. pylori seroprevalence in Brazilians varies and is dependent on socioeconomic status, sanitation conditions and ethnicity; furthermore, H. pylori is not always associated with the incidence of gastric cancer, suggesting the role of more virulent strains. The purpose of this study was to analyze the association of more virulent $H$. pylori strains with gastric cancer.

Methods: DNA was extracted from gastric biopsies of thirty-four cases of gastric cancer (11 intestinal-type, 23 diffuse-type), and thirty-four of patients with endoscopic gastritis. The presence of cagPAl genes (cagA, cagA promoter, cagE, cagM, tnpB, tnpA, cagT and the left end of the cagll (LEC)) and babA were analyzed by PCR.

Results: Comparison of $\mathrm{H}$. pylori isolates from gastric cancer and gastritis patients showed significant associations of tnpA and LEC with gastric cancer (73.5\% [OR, 6.66; 95\% Cl, 2.30-19.25] and 58.8\% [OR, 10.71; 95\% Cl, 3.07-37.28] of cases, respectively). Other cagPAl genes were detected in both groups at similar frequencies.

Conclusions: tnpA and LEC of $H$. pylori cagPAI were associated with gastric cancer; nonetheless, these results were restricted within this group of patients and further studies are needed to confirm these results in a larger sample and determine their role in gastric carcinogenesis.
\end{abstract}

\section{Findings}

The seroprevalence of $H$. pylori ranges among Brazilians, and is dependent on age, socioeconomic status, and ethnicity, as well as sanitation conditions. High prevalence has been reported in the city of Fortaleza, with $73.3 \%$ positive cases in individuals $11-20$ years old, and up to $87 \%$ in those over 60 years old [1]. Notably, the incidence rate of gastric cancer is lower $(16 / 100,000)$ in Fortaleza than in the city of São Paulo $(22 / 100,000)$ http://www.inca.gov.br/, which has a lower prevalence of H. pylori (65.6\%) [2]. Furthermore, H. pylori seroprevalence was higher in African Brazilians compared to Caucasoids [2] and Japanese Brazilians [3], despite the higher mortality for gastric cancer among Japanese Brazilians compared to the indigenous population [4]. These conflicting results suggest among other factors

\footnotetext{
* Correspondence: rejane-mattar@ig.com.br Department of Gastroenterology, University of São Paulo School of Medicine, Av Dr Enéas de Carvalho Aguiar 255, $9^{\circ}$ andar sala 9159, São Paulo, 05403000, SP, Brazil
}

(c) 2010 Mattar et al; licensee BioMed Central Ltd. This is an Open Access article distributed under the terms of the Creative Commons Attribution License (http://creativecommons.org/licenses/by/2.0), which permits unrestricted use, distribution, and reproduction in any medium, provided the original work is properly cited. that more virulent $H$. pylori strains may be involved in gastric cancer outcome.

The cag (cytotoxin-associated gene) pathogenicity island (cagPAI) in H. pylori contains 31 putative genes [5] and encodes a type IV secretion system that delivers CagA into the cytosol, which is phosphorylated and activates phosphatase activity to initiate morphological changes of the cell, providing a potential mechanism by which chronic $H$. pylori infection may promote the development of gastric cancer [6]. We previously showed that the $\operatorname{cagPAI}$ genes $\operatorname{cag} T, \operatorname{cag} M, \operatorname{cagA}$ and LEC (the left end of the cagII) were significantly associated with peptic ulcers [7], and these findings were later confirmed by another group in Brazil [8]. The purpose of this study was to analyze the association of cagPAI genes and the blood group antigen binding adhesin babA of $H$. pylori with gastric cancer.

Patients were from the indigenous population of the city of São Paulo and were classified according to ethnicity as White, Brown (of White and African-Brazilian descent) and Black, none was Japanese-Brazilian. Among 
68 consecutive gastric cancer patients, only 34 (11 intestinal-type, 23 diffuse-type) were $H$. pylori positive, 20 of which were men and 14 were women; the patients' mean age was $53.3 \pm 12.4$ years, and ranged from 24 to 75 years old; the median age was 52.5 years; 25 were White, 7 were Brown and 2 were Black.

Controls were selected among dyspeptic patients without previous history of peptic ulcer and gastric cancer, presenting a recent diagnosis of only gastritis (superficial or erosive) by upper gastrointestinal endoscopy, and positive for $H$. pylori infection. Of the 34 controls, 23 were women and 11 were men, with a mean age of 50.9 \pm 9.8 years and a range from 32 to 70 years old; the median age was 48.5 years; 29 were White, 4 were Brown and 1 was Black.

The criteria for $\mathrm{H}$. pylori positivity were the same for patients and controls, positive urease test and PCR with primers that amplify the species-specific $26-\mathrm{kDa}$ antigen gene, using antrum and corpus biopsies [7,9]. Patients and controls had not taken antimicrobials and acid suppression drugs for at least 30 days before the sample collection. In patients with gastric cancer, fragments were obtained from the normal appearance mucosa either by upper gastrointestinal endoscopy or after gastrectomy, immediately after opening the stomach. All patients provided informed written consent, and this study was approved by the local Ethics Committee.

DNA extraction from gastric biopsies of the positive urease tests and PCR were performed according to previously reported techniques. PCR analysis amplified regions of the cagPAI genes, $b a b A$, and DNA sequence of a $26-\mathrm{kDa}$ species-specific protein antigen present in all strains of $H$. pylori $[7,9]$. All the cases were confirmed H. pylori positive by urease test and by PCR for the species-specific antigen.

Fisher's exact probability test was determined using SPSS, and the odds ratio [OR] and 95\% confidence interval $[95 \% \mathrm{CI}]$ were calculated using Microsoft Office Excel 2003. A value of $P<0.05$ was considered statistically significant. The $[\mathrm{OR}]$ and $[95 \% \mathrm{CI}]$ are depicted in Table 1.

Comparison of the presence of cagPAI genes in $H$. pylori isolates from patients with gastric cancer and gastritis revealed that only two genes were significantly associated with gastric cancer: $\operatorname{tnp} A$, detected in $73.5 \%$ $(25 / 34)$ of the gastric cancer cases, with an odds ratio of 6.66 [95\% CI, 2.30-19.25], and LEC, observed in 58.8\% $(20 / 34)$ of cases, with an odds ratio of 10.71 [95\% CI, 3.07-37.28]. The other cagPAI genes analyzed in this study were detected equally in both groups. cagA was more frequently found in the gastric cancer group, though this difference was not significant; however, its presence may still be associated with gastric cancer, due to the odds ratio of 1.77 [CI 95\%: 0.61-5.11]. The babA
Table 1 Prevalence of cagPAl genes and babA in H. pylori isolates from gastritis and gastric cancer patients.

\begin{tabular}{llllll}
\hline Genes & $\begin{array}{l}\text { Controls } \\
(\mathbf{n}=\mathbf{3 4})\end{array}$ & $\begin{array}{l}\text { Gastric cancer } \\
\mathbf{( n = 3 4 )}\end{array}$ & $\boldsymbol{P}$ value & OR & $\mathbf{9 5 \%} \mathbf{C l}$ \\
\hline cagA & $8(23.5 \%)$ & $12(35.3 \%)$ & $P=0.287$ & 1.77 & $0.61-5.11$ \\
cagE & $24(70.6 \%)$ & $22(64.7 \%)$ & $P=0.604$ & 0.76 & $0.27-2.11$ \\
cagM & $8(23.5 \%)$ & $6(17.6 \%)$ & $P=0.549$ & 0.69 & $0.21-2.27$ \\
cagT & $16(47.1 \%)$ & $16(47.1 \%)$ & $P=1.000$ & 1.00 & $0.38-2.59$ \\
apcag & $20(58.8 \%)$ & $23(67.6 \%)$ & $P=0.451$ & 1.46 & $0.54-3.94$ \\
LEC & $4(11.8 \%)$ & $20(58.8 \%)$ & $P<0.0001$ & 10.71 & $3.07-37.28$ \\
tnpA & $10(29.4 \%)$ & $25(73.5 \%)$ & $P<0.0001$ & 6.66 & $2.30-19.25$ \\
tnpB & $1(2.9 \%)$ & $2(5.9 \%)$ & $P=0.551$ & 2.06 & $0.17-23.88$ \\
babA & $22(64.7 \%)$ & $14(41.2 \%)$ & $P=0.052$ & 0.38 & $0.14-1.01$ \\
\hline P 0.0001 by Fisher's exact
\end{tabular}

$P<0.0001$ by Fisher's exact probability test

gene was more often found in H. pylori isolates from patients with gastritis $(64.7 \%, 22 / 34)$ than in isolates from gastric cancer $(41.2 \%, 14 / 34 ; \mathrm{p}=0.052)$, [OR, 0.38; 95\% CI, 0.14-1.01]. The analysis of cagPAI and babA genes among the histological types (diffuse and intestinal) of gastric cancer, gender and the ethnic groups revealed no significant difference, data not shown.

As shown in Table 2, H. pylori isolates from gastric cancer cases were usually positive for both LEC and $\operatorname{tnpA}(p=0.017$ by Fisher's exact test). In Japan association of IS605 with other cagPAI genes, cag13 and cagA was previously reported in gastric cancer cases. However, as the role of this finding remains unclear, further study is necessary to determine its involvement in gastric cancer [10].

In this study, we analyzed the prevalence of $H$. pylori genes in patients from a Brazilian population with gastric cancer or gastritis. Unexpectedly, $b a b A$, the bloodgroup antigen binding adhesion targeting human Lewis ${ }^{\mathrm{b}}$ surface epitopes on gastric epithelial cells associated with duodenal ulcer and gastric adenocarcinoma [11], was frequently deleted in gastric cancer $H$. pylori isolates (41.2\%), compared to gastritis (64.7\%); nonetheless, in the previously studied peptic ulcer group, $69.3 \%$ of $H$. pylori isolates also were $b a b A$ positive [9]. Thus, $b a b A$ may be a frequent genotype with no particular role in the clinical outcome [12].

We previously showed that the $\operatorname{cagPAI}$ genes $\operatorname{cag} T$, $\operatorname{cag} A, \operatorname{cag} M$ and LEC were associated with peptic ulceration progression [7]; this study revealed that only LEC

Table 2 Association of tnpA and LEC in H. pylori isolates from patients with gastric cancer.

\begin{tabular}{llll}
\hline Gastric cancer patients $(\mathbf{n}=\mathbf{3 4})$ & $\operatorname{tn} p \boldsymbol{A}-$ & $\operatorname{tn} \boldsymbol{p A}+$ & Total \\
\hline LEC - & 7 & 7 & 14 \\
LEC $+^{*}$ & 2 & $18^{*}$ & 20 \\
\hline Total & 9 & 25 & 34 \\
\hline
\end{tabular}

${ }^{*} p=0.017$ by Fisher's exact probability test 
and $\operatorname{tnp} A$ were associated with gastric cancer. In South Africa, LEC was frequently deleted in isolates from gastritis compared to those from gastric cancer and peptic ulcers [13]. Nevertheless, LEC was not necessary for either the translocation of CagA that mediates intracellular disruption of growth regulation [14], or for the induction of IL-8 [15], proinflammatory cytokine released upon $H$. pylori infection by gastric epithelial cells that induced expression and activation of epidermal growth factor receptor and proliferation [16]. Our finding is consistent with a previous study reporting higher frequency of $\operatorname{tnpA}$ in Peruvian gastric cancer strains than in gastritis strains ( 9 of 14 versus 15 of 45 , respectively; $P=0.04$ ) [17].

We did not observe any significant association of cagA with cases of gastric cancer or gastritis, and this is consistent with previous reports in South Africa [13] and Germany [18], which failed to detect an association with gastric cancer.

Our study of a population in Brazil indicates an association with LEC and tnpA and gastric cancer; nonetheless, further studies are needed to confirm these results in a larger sample, as no specific role for these genes in gastric carcinogenesis has yet been identified.

\section{Abbreviations \\ cagPAl: cytotoxin-associated gene pathogenicity island; LEC: left end of cagll region}

\section{Acknowledgements}

The authors thank Luis Claudio Alfaia Mendes for performing endoscopies of several patients and Démerson André Polli for helping with the statistical analysis. The molecular genetic studies were partially supported by CAPES (Coordenação de aperfeiçoamento de pessoal de nível superior) and Fundação Faculdade de Medicina. Publication charges and English revision were supported by Fundação Faculdade de Medicina and CAPES/University of São Paulo School of Medicine.

\section{Authors' contributions}

RM participated in the conception, design, analysis and interpretation of data, statistical analysis, drafted the manuscript and revised final version; MSM carried out the molecular genetic studies; SBM and CLH obtained gastric biopsies; BZ provided gastric cancer patients and presented the study at the $8^{\text {th }}$ International Gastric Cancer Congress; FJC gave final approval of the version to be published. All authors read and approved the final manuscript.

\section{Competing interests}

The authors declare that they have no competing interests.

Received: 2 July 2009

Accepted: 11 January 2010 Published: 11 January 2010

\section{References}

1. Rodrigues MN, Queiroz DMM, Rodrigues RT, Rocha AMC, Luz CRL, Braga LLBC: Prevalence of Helicobacter pylori infection in Fortaleza, Northeastern Brazil. Rev Saúde Publica 2005, 39:847-849.

2. Zaterka S, Eisig JN, Chinzon D, Rothstein W: Factors related to Helicobacter pylori prevalence in an adult population in Brazil. Helicobacter 2007, 12:82-88.

3. Ito LS, Oba SM, Hamajima N, Marie SK, Uno M, Shinjo SK, Kino A, Lavilla F, Inoue M, Tajima K, Tominaga S: Helicobacter pylori seropositivity among
963 Japanese Brazilians according to sex, age, generation, and lifestyle factors. Jpn J Cancer Res 2001, 92:1150-1156.

4. Tsugane S, Gotlieb SL, Laurenti R, de Souza JM, Watanabe S: Cancer mortality among Japanese residents of the city of São Paulo, Brazil. Int J Cancer 1990, 45:436-439.

5. Censini S, Lange C, Xiang Z, Crabtree JE, Ghiara P, Borodovsky M, Rappuoli R, Covacci A: cag, a pathogenicity island of Helicobacter pylori, encodes type I-specific and disease-associated virulence factors. Proc Natl Acad Sci USA 1996, 93:14648-14653.

6. Covacci A, Rappuoli R: Tyrosine-phosphorylated bacterial proteins: Trojan horses for the host cell. J Exp Med 2000, 191:587-592.

7. Mattar R, Marques SB, Monteiro MS, Santos AF, Iriya K, Carrilho FJ: Helicobacter pylori cag pathogenicity island genes: clinical relevance for peptic ulcer disease development in Brazil. J Med Microbiol 2007, 56:9-14.

8. Pacheco AR, Proença-Módena JL, Sales AlL, Fukuhara Y, da Silveira WD, Pimenta-Módena $\mathrm{J} L$, de Oliveira RB, Brocchi M: Involvement of the Helicobacter pylori plasticity region and cag pathogenicity island genes in the development of gastroduodenal diseases. Eur J Clin Microbiol Infect Dis 2008, 27:1053-1059.

9. Mattar R, Santos AF, Eisig JN, Rodrigues TN, Silva FM, Lupinacci RM, Iriya $K$, Carrilho FJ: No correlation of babA2 with vacA and cagA genotypes of Helicobacter pylori and grading of gastritis from peptic ulcer disease patients in Brazil. Helicobacter 2005, 10:601-608.

10. Deguchi R, Igarashi M, Watanabe K, Takagi A: Analysis of the cag pathogenicity island and IS605 of Helicobacter pylori strains isolated from patients with gastric cancer in Japan. Aliment Pharmacol Ther 2004, 20(Suppl 1):13-16.

11. Gerhard M, Lehn N, Neumayer N, Boren T, Rad R, Schepp W, Miehlke S, Classen M, Prinz C: Clinical relevance of the Helicobacter pylori gene for blood-group antigen-binding adhesin. Proc Natl Acad Sci USA 1999, 96:12778-12783.

12. Sheu B-S, Sheu S-M, Yang H-B, Huang A-H, Wu J-J: Host gastric Lewis expression determines the bacterial density of Helicobacter pylori in babA2 genopositive infection. Gut 2003, 52:927-932.

13. Kidd M, Lastovica AJ, Atherton JC, Louw JA: Conservation of the cag pathogenicity island is associated with vac $\mathrm{A}$ alleles and gastroduodenal disease in South African Helicobacter pylori isolates. Gut 2001, 49:11-17.

14. Necchi V, Candusso ME, Tava F, Luinetti O, Ventura U, Fiocca R, Ricci V, Solcia E: Intracellular, intercellular, and stromal invasion of gastric mucosa, preneoplastic lesions, and cancer by Helicobacter pylori. Gastroenterology 2007, 132:1009-1023.

15. Fischer W, Püls J, Buhrdorf R, Gebert B, Odenbreit S, Haas R: Systematic mutagenesis of the Helicobacter pylori cag pathogenicity island: essential genes for CagA translocation in host cells and induction of interleulin-8. Mol Microbiol 2001, 42:1337-1348.

16. Beswick EJ, Reyes VE: Macrophage migration inhibitory factor and interleukin-8 produced by gastric epithelial cells during Helicobacter pylori exposure induce expression and activation of the epidermal growth factor receptor. Infect Immun 2008, 76:3233-3240.

17. Kersulyte D, Velapatiño B, Dailide G, Mukhopadhyay AK, Ito Y, Cahuayme L, Parkinson AJ, Gilman RH, Berg DE: Transposable element ISHp608 of Helicobacter pylori: nonrandom geographic distribution, functional organization, and insertion specificity. J Bacteriol 2002, 184:992-1002.

18. Backert S, Schwarz T, Miehlke S, Kirsch C, Sommer C, Kwok T, Gerhard M, Goebel UB, Lehn N, Koenig W, Meyer TF: Functional analysis of the cag pathogenicity island in Helicobacter pylori isolates from patients with gastritis, peptic ulcer and gastric cancer. Infect Immun 2004, 72:1043-1056.

doi:10.1186/1750-9378-5-1

Cite this article as: Mattar et al.: Association of LEC and tnpA Helicobacter pylori genes with gastric cancer in a Brazilian population. Infectious Agents and Cancer 2010 5:1. 